\title{
THE EFFECT OF DATE OF PLANTING SEEDLINGS AND POLYPROPYLENE FIBRE COVERING ON THE YIELD AND ECONOMIC EFFICIENCY OF MELON
}

\author{
Robert Rosa', Edyta Kosterna-Kelle', Jolanta Franczuk', \\ Anna Zaniewicz-Bajkowska', Marzena Panasz ${ }^{1}$ \\ 1 Department of Vegetable Crops, Siedlce University of Natural Sciences and Humanities, Bolesława Prusa 14, \\ 08-110 Siedlce, Poland, e-mail: robert.rosa@uph.edu.pl
}

Received: 2016.10.13

Accepted: 2016.11.10

Published: 2017.01.01

\begin{abstract}
Melon is a little popular vegetable to grow in Poland, due to high climatic requirements. Ensuring appropriate thermal conditions for plants growth is possible with relatively late planting seedlings. However, late planting does not guarantee high yield of good quality fruit. The factor enabling the earlier planting seedlings and improving the conditions of growth is the use of flat covers. The field experiment was conducted in 2008-2010 in central-eastern Poland. The effect of planting seedlings of melon 'Malaga $\mathrm{F}_{1}$ ' (15 May, 25 May and 4 June) and the length of polypropylene fibre $17 \mathrm{~g} \cdot \mathrm{m}^{-2}$ covering (by 4 and 8 weeks from planting, until harvest, control without covering) on the yield and economic efficiency of melon cultivation in the field was investigated. Most preferably the yield level and profitability of melon cultivation were influenced by planting seedlings on the 15 May and covering by 4 weeks. However, earlier planting decreased the share of marketable fruits in the total number of fruits. The highest share in the costs structure of melon cultivation had the costs of human labour.
\end{abstract}

Keywords: Cucumis melo L., cultivation date, economic efficiency, polypropylene fibre, yield

\section{INTRODUCTION}

Melon belongs to the thermophilic vegetables with high environmental requirements, therefore, treatments, which improve climate conditions are necessary in its production [Majkowska-Gadomska 2009]. An important problem in the field melon cultivation in Poland is the late date of planting seedlings ( $1^{\text {st }} 10$ days of June) due to its sensitivity on the low air and soil temperature. In the colder years, fruit from plants planted at this time, does not reach maturity before the autumn frost. In the field cultivation an important element of agricultural technology, protecting thermophilic vegetables against unfavorable thermal conditions, is flat polypropylene fibre covering. Covering provides better thermal and moisture conditions for plants, resulting in an acceleration of the yield [Siwek and Lipow- iecka 2003, Lamont 2005, Hamouz et al. 2006, Majkowska-Gadomska 2009, Rosa 2014].

Previous studies Kosterna et al. [2009] and Majkowskiej-Gadomskiej [2009, 2010] have shown that by the use of flat covers in Poland it is possible to obtain a satisfactory yield of mature, valuable and tasty fruits of melon, even if the summer months were characterized by lower than the long-term air temperature.

Barrier to the availability of melon fruit for a wide range of consumers is its high price. According to Waterer [2003, 2010], Yilmaz et al. [2011] and Benincasa et al. [2014] the main cost of melon cultivation is the cost of covers and hand fruit harvesting.

The study aimed to determine the effect of differentiated date of planting seedlings and the date of polypropylene fibre removal on the yield and economic efficiency of melon cultivation in the climatic conditions of central-eastern Poland. 


\section{MATERIAL AND METHODS}

The experiment was conducted in 2008-2010 in central-eastern Poland $\left(51^{\circ} 53^{\prime} \mathrm{N}, 2^{\circ} 27^{\prime} \mathrm{E}\right)$. The experiment was established as a split-block design with four replicates. The area of one plot for harvest was $12 \mathrm{~m}^{2}$. The influence of two factors was investigated: I. the date of melon seedlings planting: $4^{\text {th }}$ of June - traditionally recommended in Poland, $25^{\text {th }}$ of May - date accelerated by 10 days, $15^{\text {th }}$ of May - date accelerated by 20 days; II. Plants covering: by 4 and 8 weeks after planting seedlings, to fruits harvest, control without covering.

The field experiment was carried out on the soil classified as Podzols [World reference... 2014]. Soil was characterized by a humus level of $37-43 \mathrm{~cm}$. Mean content of organic carbon was $2.1 \%$, the value of $\mathrm{pH}$ determined in $\mathrm{H}_{2} \mathrm{O}$ was 5.80 . Macroelements content in $1 \mathrm{dm}^{3}$ in the arable layer was as follows: $14 \mathrm{mg} \mathrm{N}-\mathrm{NH}_{4} ; 20 \mathrm{mg} \mathrm{N}-\mathrm{NO}_{3}$; $19 \mathrm{mg} \mathrm{P}_{2} \mathrm{O}_{5} ; 145 \mathrm{mg} \mathrm{K}_{2} \mathrm{O} ; 797 \mathrm{mg} \mathrm{Ca} ; 76 \mathrm{mg} \mathrm{Mg}$.

Melon seedlings 'Malaga' were grown in non-heated greenhouse. The seeds were sown 4 weeks before the date of planting seedlings i.e. $17^{\text {th }}$ of April, $27^{\text {th }}$ of April and $7^{\text {th }}$ of May. During the seedlings growth, solution of liquid foliar feeds Florovit at $0.5 \%$ was applied, which represent a multi-nutrient fertiliser. Forecrop for melons was corn grown for silage. Soil preparation included deep plowing and harrowing in early spring. In the first 10 days of May mineral fertilization was applied. The nutrient content in the soil was made up to the optimum level for cucumber [in $\mathrm{mg}^{\cdot} \mathrm{dm}^{-3}$ ]: $70 \mathrm{~N}, 80 \mathrm{P}, 200 \mathrm{~K}$, $80 \mathrm{Mg}, 1500 \mathrm{Ca}$ [Sady 2000]. These standards are also accepted for field-grown melon. Melon belongs to the same botanical family, and has similar requirements for fertilisation. Fertilizers were mixed with the soil using the aggregate cultivar. The melon seedlings were planted on the soil covered with black polypropylene nonwoven, at a spacing of $80 \times 100 \mathrm{~cm}$.

Fruit harvesting was performed gradually, as fruit ripened. During the last harvest all the fruits, also unripe were collected. During the harvest the total yield $\left[\mathrm{kg} \cdot \mathrm{m}^{-2}\right]$, marketable yield $\left[\mathrm{kg} \cdot \mathrm{m}^{-2}\right]$, number of marketable fruits $\left[\right.$ no. $\left.\mathrm{m}^{-2}\right]$, average weight of marketable fruit $[\mathrm{kg}]$ were determined. On the basis of the obtained results the percentage share of marketable yield in the total yield and number of marketable fruits in total number of fruits were calculated.
The results of the experiment were statistically analyzed by ANOVA following the mathematical model for the split-block design. Significance of differences was determined by the Tukey test at the significance level of $\mathrm{P} \leq 0.05$.

The paper also analyzes the economic cultivation of melon according to accepted by the European Union standard gross margin method (SGM) [Augustyńska-Grzymek et al. 2000]. The concept of SGM allows to avoid deviations caused by variability quantify and valuable size of production e.g. resulting from the bad weather and the variation of costs incurred for its production. The gross margin was calculated as a difference between the yield value obtained from 1 ha of melon cultivation and direct costs of production. Melon production value is the sum of the main product value, which is in the traded on the market, determined according to sales prices. The calculation of production value does not include the area payment. The purchase costs of multitray for seedling production and the costs of polypropylene fibre were divided into three years, because at their proper use and storage can be used for 3 seasons. The other elements of direct costs of production were fixed to the growing cycle of melon. They included the costs of material (sowing material, peat substrate, mineral fertilizers, plant protection means, black polypropylene fibre for soil mulching), as well as human and mechanical labour outlays, established on the basis of technology used in the experiment, labour consumption of individual measures in production conditions of the Agricultural Experimental Station in Zawady. Economic evaluation was based on the price from 2015. The value of melon production was the ratio of fruits yield (expressed by the number of fruits per $1 \mathrm{ha}$ ) and the price of a single fruit, which was established as 5.00 PLN. It was the mean price from the end of July to the end of September in the Lublin Wholesale Market in Elizówka and the Warsaw Agri-Food Wholesale Market in Bronisze [www.fresh-market.pl].

\section{RESULTS AND DISCUSSION}

In 2008, despite relatively balanced thermal conditions and uniform distribution of precipitation, the lowest total and marketable yield of melon fruits was obtained. The marketable fruits were also characterised by the lowest weight. The highest total and marketable yields and the 
most marketable fruits from $1 \mathrm{~m}^{2}$ were obtained in 2010, which was characterised by the most favourable thermal conditions during the growth period of melon. In 2009 marketable yield was lower than in 2010, but simultaneously the marketable fruits in 2009 were characterised by the highest weight (Table 1).

The total yield of melon fruits amounted to average $4.94 \mathrm{~kg} \cdot \mathrm{m}^{-2}$, and marketable yield 4.24 $\mathrm{kg} \cdot \mathrm{m}^{-2}$ (Table 2). In a study conducted in the climatic conditions of Poland by Grudzien and Górecki [2001] the total yield of melon fruits was lower by $3.71 \mathrm{~kg} \cdot \mathrm{m}^{-2}$, and by Majkowska-Gadomska [2010] by $3.60 \mathrm{~kg} \cdot \mathrm{m}^{-2}$. However, the marketable yield of 'Malaga' obtained by Grudzień and Górecki [2001] was lower by $1.70 \mathrm{~kg} \cdot \mathrm{m}^{-2}$. The melon yield in the present study was lower than achieved by Ibarra et al. [2001], which amounted to $8.25 \mathrm{~kg} \cdot \mathrm{m}^{-2}$, however, the cited authors' studies were conducted in more favourable climatic conditions (central Mexico).

The acceleration of planting seedlings by 10 and 20 days significantly increases the total and marketable yield. Compared to the traditional planting date ( $4^{\text {th }}$ of June) an increase in the total yield amounted to 17 and $28 \%$, and in marketable yield 16 and $25 \%$.

Covering contributed to a significant increase in the total and marketable yield of melon compared to cultivation without covering. Irrespective of the date of planting seedlings the total yield increased by $160-171 \%$ and marketable yield by
292-309\%. In the study by Majkowska-Gadomska [2010] covering 14-18 days contributed to a nearly double increase in marketable yield of melon 'Malaga $F_{1}$ 'compared to harvested from the control without cover. Increase of melon yield as a result of covering was also noted in Mexico by Ibarra et al. [2001], South Korea's by Shin et al. [2009] and in central Italy by Benincasa et al. [2014]. In the weather conditions of Poland it was found that the application of flat covers has a beneficial yielding effect in the cultivation of many species of thermophilic vegetables. As a result of covering increase of yields were noted by Grudzień and Rumpel [1998] in bell pepper cultivation, Wierzbicka and Kuskowska [2000] in cucumber, Kosterna [2014] in tomato and Rosa [2014] in sweet corn cultivation. In the present study, covering plants for 4 weeks contributed to a significant increase in marketable yield. Longer covering had no significant influence on the yield level. Also Ibarra et al. [2001] found an increase in marketable yield of melon as a result of covering (by 93-130\%), however, elongation of covering from 10 to 20 and 32 days did not cause a significant increase of yield. Similarly, Santos et al. [2015] did not note differences in the yield of melon covered by 18, 21, 24, 27 and 30 days after planting. However, in the study by IbarraJiménez et al. [2001] elongation of melon covering from 14 to 24 and 31 days and from 31 to 41 days caused a significant increase in marketable yield of melon fruits.

Table 1. Yields of melon in the years of study

\begin{tabular}{|c|c|c|c|c|}
\hline Years & $\begin{array}{c}\text { Total yield } \\
\left(\mathrm{kg} \cdot \mathrm{m}^{-2}\right)\end{array}$ & $\begin{array}{c}\text { Marketable yield } \\
\left(\mathrm{kg} \cdot \mathrm{m}^{-2}\right)\end{array}$ & $\begin{array}{c}\text { Number of marketable } \\
\text { fruits }\left(\mathrm{no} \cdot \mathrm{m}^{2}\right)\end{array}$ & $\begin{array}{c}\text { Weight } \\
\text { of marketable fruit } \\
(\mathrm{kg})\end{array}$ \\
\hline 2008 & $4.28 \mathrm{a}^{*}$ & $3.60 \mathrm{a}$ & $2.5 \mathrm{a}$ & $1.46 \mathrm{a}$ \\
\hline 2009 & $5.09 \mathrm{~b}$ & $4.29 \mathrm{~b}$ & $2.5 \mathrm{a}$ & $1.71 \mathrm{c}$ \\
\hline 2010 & $5.44 \mathrm{~b}$ & $4.83 \mathrm{c}$ & $2.9 \mathrm{~b}$ & $1.65 \mathrm{~b}$ \\
\hline
\end{tabular}

* Values within columns followed by the same lowercase letters are not significantly different at $\mathrm{P} \leq 0.05$

Table 2. Yields of melon (mean for 2008-2010)

\begin{tabular}{|c|c|c|c|c|c|c|c|c|}
\hline \multirow{3}{*}{ Covering } & \multicolumn{4}{|c|}{ Total yield $\left(\mathrm{kg} \cdot \mathrm{m}^{-2}\right)$} & \multicolumn{4}{|c|}{ Marketable yield $\left(\mathrm{kg} \cdot \mathrm{m}^{-2}\right)$} \\
\hline & \multicolumn{3}{|c|}{ Date of planting seedlings } & \multirow{2}{*}{ Mean } & \multicolumn{3}{|c|}{ Date of planting seedlings } & \multirow{2}{*}{ Mean } \\
\hline & 15 May & 25 May & 4 June & & 15 May & 25 May & 4 June & \\
\hline Control & $2.18 \mathrm{a}^{*}$ & $2.29 \mathrm{a}$ & $2.16 \mathrm{a}$ & $2.21 \mathrm{a}$ & $1.14 \mathrm{a}$ & $1.28 \mathrm{a}$ & $1.51 \mathrm{a}$ & $1.31 \mathrm{a}$ \\
\hline By 4 weeks after planting & $6.51 \mathrm{~b}$ & $5.95 b$ & $4.92 \mathrm{bc}$ & $5.79 \mathrm{~b}$ & $5.69 \mathrm{~b}$ & $5.34 \mathrm{~b}$ & $4.44 \mathrm{bc}$ & $5.16 \mathrm{~b}$ \\
\hline By 8 weeks after planting & $6.57 \mathrm{~b}$ & $5.95 \mathrm{~b}$ & $4.72 \mathrm{~b}$ & $5.75 \mathrm{~b}$ & $5.79 \mathrm{~b}$ & $5.25 b$ & $4.34 \mathrm{~b}$ & $5.13 \mathrm{~b}$ \\
\hline To harvest & $6.81 \mathrm{c}$ & $5.85 \mathrm{~b}$ & $5.35 \mathrm{c}$ & $6.00 \mathrm{~b}$ & $6.00 \mathrm{~b}$ & $5.36 \mathrm{~b}$ & $4.73 \mathrm{c}$ & $5.36 \mathrm{~b}$ \\
\hline Mean & $5.51 C^{* *}$ & $5.01 \mathrm{~B}$ & $4.29 \mathrm{~A}$ & 4.94 & $4.66 \mathrm{C}$ & $4.31 \mathrm{~B}$ & $3.73 \mathrm{~A}$ & 4.24 \\
\hline
\end{tabular}

* Values within columns followed by the same lowercase letters are not significantly different at $\mathrm{P} \leq 0.05$

${ }^{* *}$ Values within rows followed by the same uppercase letters are not significantly different at $\mathrm{P} \leq 0.05$ 
In the conducted study the share of marketable yield in the total yield amounted to average $81.7 \%$ (Figure 2) and was similar to the one found by Majkowska-Gadomska [2010] $81.5 \%$ and Kruk [1995] 80.3\% and significantly higher than in research conducted by Grudzień and Górecki [2001], where it was at the level of $63.4 \%$. In the weather conditions of Mexico the share of marketable yield in the total yield amounted to $78.0 \%$ [Ibarra-Jiménez et al. 2001] and 83.0\% [Ibarra et al. 2001]. In the present study the share of marketable fruits in the total number of fruits amounted to average $77.4 \%$ (Figure 2).

The acceleration of planting seedlings by 10 and 20 days compared to the date recommended in the literature ( $4^{\text {th }}$ of June) decreased the share of marketable yield in the total yield by 4.1 and
$6.5 \%$ and the number of marketable fruits in the total number of fruits by 3.2 and $3.9 \%$. Irrespective of the date of planting seedlings, use of covers influenced on the increase the share of marketable yield and the number of marketable fruits compared to the control plot without covering on average by $30 \%$. Ibarra et al. [2001] as a result of covering was noted an increase of marketable yield in the total yield from 13.5 to $20.2 \%$, however in the study by Ibarra-Jiménez et al. [2001] the share both in the covered and uncovered cultivation was similar (75-79\%).

The number of marketable fruits of melon amounted to average $2.6 \mathrm{no} \cdot \mathrm{m}^{-2}$ (Table 3). Earlier planting by 10 and 20 days compared to the June date contributed to a significant increase in the number of marketable fruits. In all dates

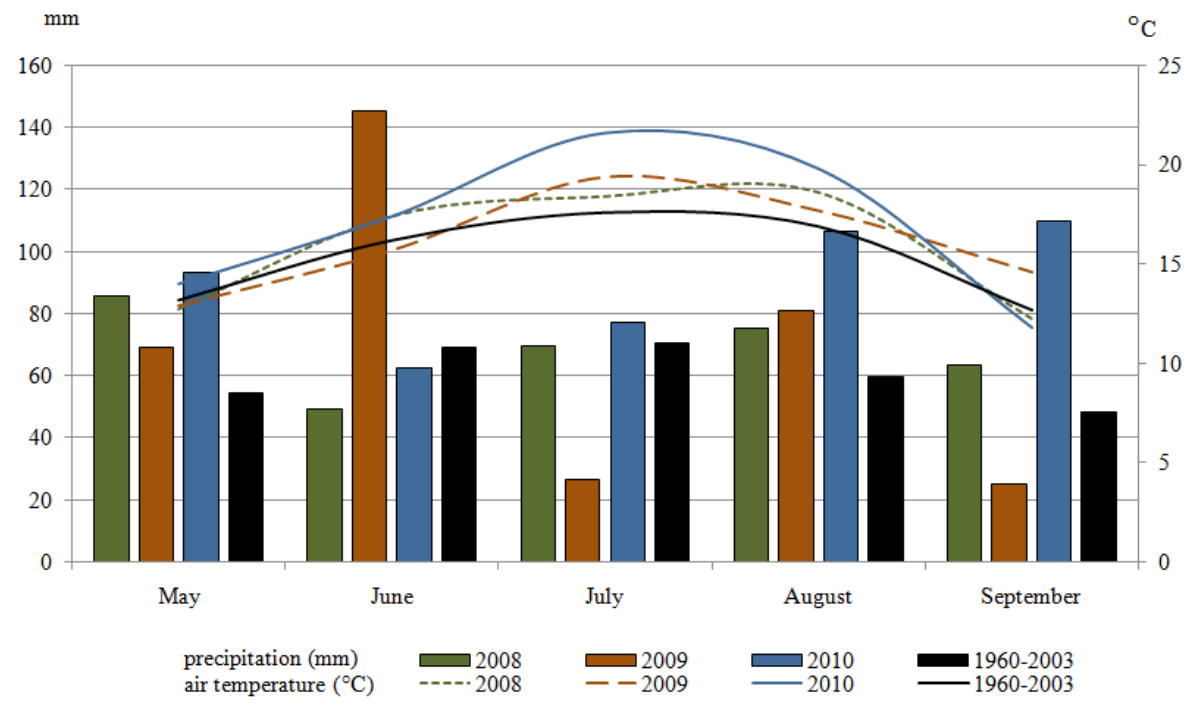

Figure 1. Weather conditions in the years of study
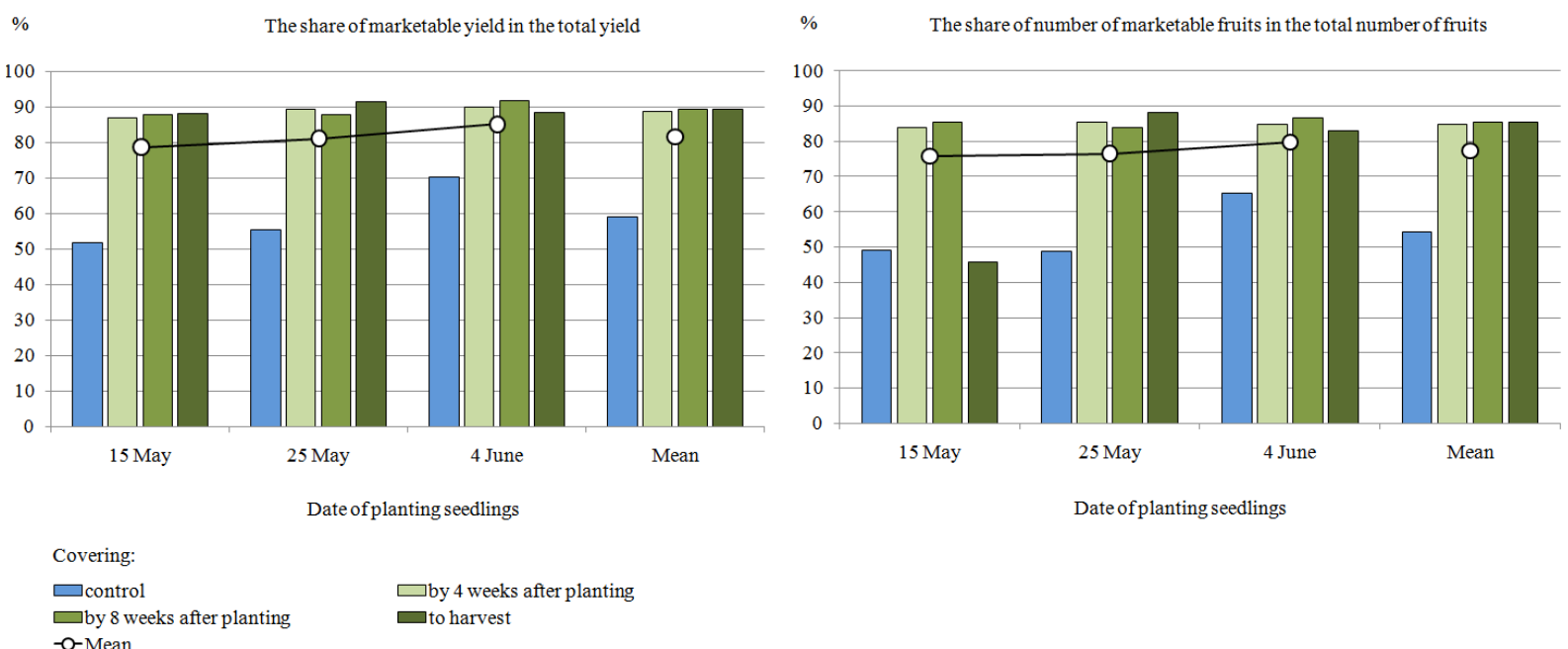

Figure 2. The share of marketable yield in the total yield (mean for 2008-2010) 
Table 3. Number and weight of marketable fruits (mean for 2008-2010)

\begin{tabular}{|c|c|c|c|c|c|c|c|c|}
\hline \multirow{3}{*}{ Covering } & \multicolumn{4}{|c|}{ Number of marketable fruits $\left(\mathrm{no} \cdot \mathrm{m}^{-2}\right)$} & \multicolumn{4}{|c|}{ Weight of marketable fruit $(\mathrm{kg})$} \\
\hline & \multicolumn{3}{|c|}{ Date of planting seedlings } & \multirow{2}{*}{ Mean } & \multicolumn{3}{|c|}{ Date of planting seedlings } & \multirow{2}{*}{ Mean } \\
\hline & 15 May & 25 May & 4 June & & 15 May & 25 May & 4 June & \\
\hline Control & $0.8 a^{*}$ & $0.8 \mathrm{a}$ & $1.0 \mathrm{a}$ & $0.9 \mathrm{a}$ & $1.47 \mathrm{a}$ & $1.53 \mathrm{a}$ & $1.55 \mathrm{a}$ & $1.52 \mathrm{a}$ \\
\hline By 4 weeks after planting & $3.4 \mathrm{~b}$ & $3.3 \mathrm{~b}$ & $2.9 \mathrm{~b}$ & $3.2 \mathrm{~b}$ & $1.68 \mathrm{~b}$ & $1.61 \mathrm{ab}$ & $1.53 \mathrm{a}$ & $1.61 \mathrm{ab}$ \\
\hline By 8 weeks after planting & $3.5 \mathrm{~b}$ & $3.2 \mathrm{~b}$ & $2.7 \mathrm{~b}$ & $3.1 \mathrm{~b}$ & $1.68 \mathrm{~b}$ & $1.64 \mathrm{~b}$ & $1.60 \mathrm{a}$ & $1.64 \mathrm{~b}$ \\
\hline To harvest & $3.5 \mathrm{~b}$ & $3.2 \mathrm{~b}$ & $2.9 \mathrm{~b}$ & $3.2 \mathrm{~b}$ & $1.70 \mathrm{~b}$ & $1.70 \mathrm{~b}$ & $1.62 \mathrm{a}$ & $1.67 \mathrm{~b}$ \\
\hline Mean & $2.8 C^{* *}$ & $2.6 \mathrm{~B}$ & $2.4 \mathrm{~A}$ & 2.6 & $1.63 \mathrm{~B}$ & $1.62 \mathrm{AB}$ & $1.58 \mathrm{~A}$ & 1.61 \\
\hline
\end{tabular}

${ }^{*},{ }^{* *}$ Explanations as in table 2

of planting seedlings, covering regardless of the length, influenced significantly on the increase in the number of marketable fruits compared to the control without covering. In the study by IbarraJiménez et al. [2001] covering the melon plants with polypropylene fibre by a period between 24 to 41 days caused increase the number of fruits per plant compared to control without cover, however Santos et al. [2015] did not find a significant influence of covering on the number of fruits.

The weight of marketable melon fruit amounted to an average of $1.61 \mathrm{~kg}$ (Table 3). Majkowska-Gadomska [2010], in the research conducted in the less favorable environmental conditions, obtained the fruits of melon 'Malaga $\mathrm{F}_{1}$ ' with a lower average weight $(1.32 \mathrm{~kg})$. Also Kosterna et al. [2009] found that average weight of six largefruit melon from the field cultivation conducted in the similar conditions was lower and amounted to $1.13 \mathrm{~kg}$. The marketable fruits from covered plants were characterized by higher weight compared to obtained from uncovered plants. Depending on the length of covering the increase in marketable fruit weight ranged from $0.09 \mathrm{~kg}$ at the covering by 4 weeks to $0.15 \mathrm{~kg}$ at the covering to harvest. Also the study results by Majkowska-Gadomska [2010] indicate that average weight of melon fruit 'Malaga $\mathrm{F}_{1}$ ' from covered cultivation was by 0.25 $\mathrm{kg}$ higher than the weight of fruits from uncovered plants. In the author's own research a significant increase in the marketable weight of fruit as a result of covering was achieved from the plants planted on the $15^{\text {th }}$ and $25^{\text {th }}$ of May (respectively by $14-15.6 \%$ and $5-11 \%$ ), however the length of covering not modify significantly this feature. In the case of plants planted on the $4^{\text {th }}$ of June, both the length of polypropylene fibre covering and just covering is not affected in a significant way on the weight of the marketable fruit. This suggests that together with the increases of temperature a positive impact of covering on the weight of the melon fruit decreases. This is confirmed by the research by Santos et al. [2015], who in the more favourable than Polish climatic conditions for the cultivation of this plant did not receive significant changes in the weight of the marketable fruit as a result of covering.

Direct production costs of melon were variable depending on the method of cultivation (covering with polypropylene fibre or without covering), the date of cover removal and the date of planting seedlings (Table 4). Differentiation elements of these costs were the costs of purchasing polypropylene fibre and also labour costs (placing and removing covers from the field, harvest, transport and packaging of fruits) and the cost of package directly related to the level of yields of melon planted in individual dates. The yield was higher, the incurred costs of harvesting and packaging of melon fruits were higher. Irrespective of the date of planting seedlings, the costs of melon cultivation without covering were lower by $50 \%$ on average, compared to cultivation with polypropylene fibre. The highest direct costs incurred for the cultivation of melon planted on the $15^{\text {th }}$ of May and covered by 8 weeks after planting seedlings and to the fruits harvest (71865 PLN $\left.\cdot \mathrm{ha}^{-1}\right)$. The highest share in the structure of direct costs (71.6-72.6\%) had the cost of human labour during seedling production, the cultivation of melon in the field and its harvesting and preparation for sale. The dominant share of costs of human labour in the structure of melon cultivation costs is also indicated by Waterer [2003] and Yilmaz et al. [2011]. In the author's own research, depending on the cultivation combination outlays of labour, ranged from 956 to 2160 man hours $\cdot \mathrm{ha}^{-1}$. Assuming the cost of human labour as 24.00 PLN per hour (valuation according to the Agricultural Experimental Station in Zawady), it gives the amount ranged from 22944 to $51840 \mathrm{PLN} \cdot \mathrm{ha}^{-1}$. The share of human labour costs in the labour costs (human labour + mechanical labour) amounted to average $96 \%$ and was higher to the found in the study by 
Table 4. The structure of direct costs $\left(\mathrm{PLN} \cdot \mathrm{ha}^{-1}\right)$ in melon cultivation depending on the date of planting seedlings and length of covering (mean for 2008-2010)

\begin{tabular}{|c|c|c|c|c|}
\hline \multirow{2}{*}{ Specification } & \multicolumn{4}{|c|}{ Covering } \\
\hline & Control & $\mathrm{C} 4^{*}$ & $\mathrm{C} 8$ & $\mathrm{CH}$ \\
\hline \multicolumn{5}{|l|}{ The costs of seedlings preparation } \\
\hline Peat substrate & 400 & 400 & 400 & 400 \\
\hline Multi-tray ** & 221 & 221 & 221 & 221 \\
\hline Fill of multi-tray & 384 & 384 & 384 & 384 \\
\hline Melon seeds & 410 & 410 & 410 & 410 \\
\hline Sowing & 192 & 192 & 192 & 192 \\
\hline Florovit & 30 & 30 & 30 & 30 \\
\hline Watering and feeding of seedlings & 480 & 480 & 480 & 480 \\
\hline Removal of tops & 144 & 144 & 144 & 144 \\
\hline \multicolumn{5}{|l|}{ The costs of melon cultivation in the field } \\
\hline Winter plowing & 260 & 260 & 260 & 260 \\
\hline Harrowing & 80 & 80 & 80 & 80 \\
\hline Mineral fertilizers & 1865 & 1865 & 1865 & 1865 \\
\hline Fertilizers spreading & 130 & 130 & 130 & 130 \\
\hline Cultivation unit & 190 & 190 & 190 & 190 \\
\hline Black polypropylene fibre ${ }^{* *}$ & 1760 & 1760 & 1760 & 1760 \\
\hline Black polypropylene fibre placing & 7200 & 7200 & 7200 & 7200 \\
\hline Planting seedlings & 6000 & 6000 & 6000 & 6000 \\
\hline Polypropylene fibre ${ }^{* *}$ & - & 1440 & 1440 & 1440 \\
\hline Polypropylene fibre covering & - & 4800 & 4800 & 4800 \\
\hline $\begin{array}{l}\text { Covering and uncovering for the application of plant } \\
\text { protection means }\end{array}$ & - & - & 1440 & 1440 \\
\hline Plant protection means & 396 & 396 & 396 & 396 \\
\hline Spraying of plant protection means & 376 & 376 & 376 & 376 \\
\hline Removal of polypropylene fibre & - & 1920 & 1920 & 1920 \\
\hline Removal of black polypropylene fibre & 2400 & 2400 & 2400 & 2400 \\
\hline \multicolumn{5}{|c|}{ The costs of harvest and packaging depending on the number of fruits harvested from the plants planted in different dates } \\
\hline 15 May & 6144 & 26112 & 26880 & 26880 \\
\hline 25 May & 6144 & 25344 & 24576 & 24576 \\
\hline 4 June & 7680 & 22272 & 20736 & 22272 \\
\hline \multicolumn{5}{|l|}{ The costs of transport melon from the field } \\
\hline 15 May & 160 & 800 & 800 & 800 \\
\hline 25 May & 160 & 720 & 720 & 720 \\
\hline 4 June & 240 & 640 & 560 & 640 \\
\hline \multicolumn{5}{|c|}{ The costs of package depending on the number of fruits harvested from the plants planted in different dates } \\
\hline 15 May & 2667 & 11333 & 11667 & 11667 \\
\hline 25 May & 2667 & 11000 & 10667 & 10667 \\
\hline 4 June & 3333 & 9667 & 9000 & 9667 \\
\hline \multicolumn{5}{|l|}{ Total direct costs } \\
\hline 15 May & 31889 & 69323 & 71865 & 71865 \\
\hline 25 May & 31889 & 68142 & 68481 & 68481 \\
\hline 4 June & 34171 & 63657 & 62814 & 65097 \\
\hline
\end{tabular}

* C4 - by 4 weeks after planting, $\mathrm{C} 8$ - by 8 weeks after planting, $\mathrm{CH}$ - to harvest

** $1 / 3$ costs of multi-tray, polypropylene fibre and black polypropylene fibre application

Yilmaz et al. [2011], in which amounted to $88 \%$ costs of labour in the melon cultivation.

The highest value of melon production (175000 PLN) and the highest gross margin per 1 ha (103135 PLN) was obtained for melon cultivated from seedlings planted on the $15^{\text {th }}$ of May and covered with polypropylene fibre by 8 weeks after planting or until the harvest (Table 5). The highest gross margin per 1 fruit and gross mar- gin per 1 PLN of incurred costs (2.95-2.96 PLN and 1.44-1.45 PLN) were calculated for melon planted on the $15^{\text {th }}$ of May and covered with polypropylene fibre, irrespective of the date of its removal. In the conducted experiment, profitability index of melon production ranged from 125 to 245\% (Figure 3). Yilmaz et al. [2011] also point to a high profitability of melon production in the conditions of Turkey. In the climatic conditions of 
Table 5. Value, direct costs and gross margin (PLN) of melon production depending on the date of planting seedlings and length of covering (mean for 2008-2010)

\begin{tabular}{|c|c|c|c|c|c|c|c|c|c|c|c|c|}
\hline \multirow{3}{*}{ Specification } & \multicolumn{12}{|c|}{ Date of planting seedlings } \\
\hline & \multicolumn{4}{|c|}{15 May } & \multicolumn{4}{|c|}{25 May } & \multicolumn{4}{|c|}{4 June } \\
\hline & Control & $\mathrm{C} 4^{*}$ & C8 & $\mathrm{CH}$ & Control & C4 & C8 & $\mathrm{CH}$ & Control & $\mathrm{C} 4$ & C8 & $\mathrm{CH}$ \\
\hline $\begin{array}{l}\text { Number of marketable } \\
\text { fruits per } 1 \text { ha }\end{array}$ & 8000 & 34000 & 35000 & 35000 & 8000 & 33000 & 32000 & 32000 & 10000 & 29000 & 27000 & 29000 \\
\hline Production value (PLN) & 40000 & 170000 & 175000 & 175000 & 40000 & 165000 & 160000 & 160000 & 50000 & 145000 & 135000 & 145000 \\
\hline $\begin{array}{l}\text { Total direct costs per } 1 \\
\text { ha (PLN) }\end{array}$ & 31889 & 69323 & 71865 & 71865 & 31889 & 68142 & 68481 & 68481 & 34171 & 63657 & 62814 & 65097 \\
\hline $\begin{array}{l}\text { Direct costs of } 1 \text { melon } \\
\text { fruit production }\end{array}$ & 3.99 & 2.04 & 2.05 & 2.05 & 3.99 & 2.06 & 2.14 & 2.14 & 3.42 & 2.20 & 2.33 & 2.24 \\
\hline $\begin{array}{l}\text { Gross margin per } 1 \text { ha } \\
\text { (PLN) }\end{array}$ & 8111 & 100677 & 103135 & 103135 & 8111 & 96858 & 91519 & 91519 & 15829 & 81343 & 72186 & 79903 \\
\hline $\begin{array}{l}\text { Gross margin per } 1 \\
\text { melon fruit (PLN) }\end{array}$ & 1.01 & 2.96 & 2.95 & 2.95 & 1.01 & 2.94 & 2.86 & 2.86 & 1.58 & 2.80 & 2.67 & 2.76 \\
\hline $\begin{array}{l}\text { Gross margin per } 1 \text { PLN } \\
\text { of costs (PLN) }\end{array}$ & 0.25 & 1.45 & 1.44 & 1.44 & 0.25 & 1.42 & 1.34 & 1.34 & 0.46 & 1.28 & 1.15 & 1.23 \\
\hline
\end{tabular}

* $\mathrm{C} 4$ - by 4 weeks after planting, $\mathrm{C} 8$ - by 8 weeks after planting, $\mathrm{CH}$ - to harvest

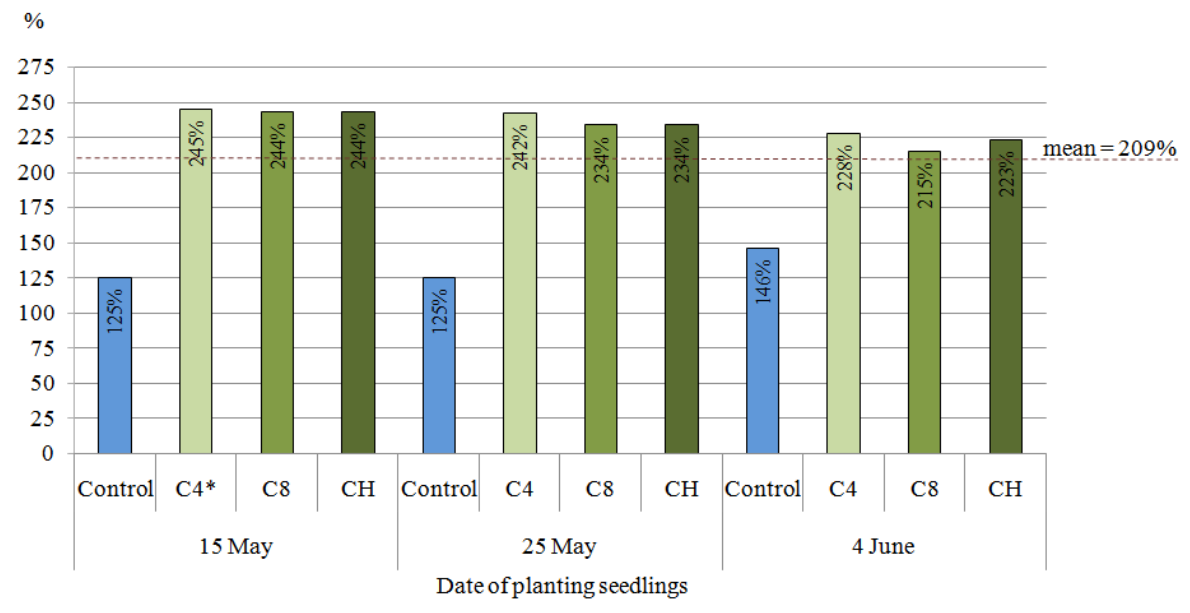

* $\mathrm{C} 4$ - covering by 4 weeks after planting, $\mathrm{C} 8$ - covering by 8 weeks after planting, $\mathrm{CH}$ - covering to harvest

Figure 3. Profitability index (\%) of melon cultivation

Poland, high profitability of cucumbers cultivation under covers was noted Siwek et al. [2003], tomato and eggplant Gunerka et al. [2014]. Irrespective of the date of planting seedlings of melon use of covers with polypropylene fibre was a factor increasing the profitability of crops in comparison with the cultivation without covering. The higher economic effect was achieved by planting melon seedlings on the $15^{\text {th }}$ of May and covered with polypropylene fibre (244-245\%). The later was date of planting seedlings, the increase in profitability index as a result of covering was lower. High average profitability index of melon production at the level of $209 \%$, especially in the era of continuous reduction of the profitability of agricultural production, at the increasing market requirements can provide an incentive for Polish agricultural producers to take an interest in its cultivation.

\section{CONCLUSIONS}

1. Weather conditions have a significant influence on the yield of melon 'Malaga F1'. In all years of the study yields achieved in the weather conditions of central-eastern Poland were satisfying. In these conditions is possible cultivation of melon in the field from seedlings planted on the 15 th of May.

2. The earliest planting date had the most beneficial effect on the total and marketable yield and average weight of the marketable fruit. From the plants planted in both dates in May significantly more fruits were obtained from the cultivation area than from the plants planted on the 4th of June.

3. The total and marketable yield and average weight of the marketable fruit from covered plants was significantly higher than from un- 
covered plants. The length of covering had no significant effect on these yield parameters. For the size and quality of the yield was essential to protect plants against unfavorable weather conditions during the first four weeks after planting to the field. Irrespective of the length of covering, the share of marketable yield in the total yield increased compared to uncovered plants.

4. Economic analysis of the cultivation of melon showed the close relationship between the level of achieved yield of melon and incurred human labour outlays per unit area.

5. The higher economic effect was obtained from the seedlings planted on the 15th of May and covered with polypropylene fibre by 4 weeks.

\section{REFERENCES}

1. Augustyńska-Grzymek I., Goraj L., Jarka S., Pokrzywa T., Skarżyńska A. 2000. Metodyka liczenia nadwyżki bezpośredniej i zasady typologii gospodarstw rolniczych. Warszawa, FAPA.

2. Benincasa P., Massoli A., Polegri L., Concezzi L., Onofri A., Teil F. 2014. Optimising the use of plastic protective covers in field grown melon on a farm scale. Italian Journal of Agronomy, 9, 556. DOI 10.4081/ija.2014.556

3. Grudzień K., Górecki R. 2001. The effect of sheltering plants on field of cucumber and muskmelon. Vegetable Crops Research Bulletin, 54, 69-73.

4. Grudzień K., Rumpel J. 1998. Wpływ osłaniania i ściółkowania gleby na plonowanie papryki. Zeszyty Naukowe ATR w Bydgoszczy, s. Rolnictwo, 215(42), 79-84.

5. Gunerka L., Jabłońska L., Milczarski M. 2014. Opłacalność produkcji warzyw pod osłonami na przykładzie wybranego gospodarstwa. Roczniki Naukowe Ekonomii Rolnictwa i Rozwoju Obszarów Wiejskich., 101(3), 77-86.

6. Hamouz K., Lachman J., Dvořák P., Trnková E. 2006. Influence of non-woven fleece on the yield formation of early potatoes. Plant, Soil and Environment, 52(7), 289-294.

7. Ibarra L., Flores J., Díaz-Pérez J. C. 2001. Growth and yield of musk melon in response to plastic mulch and row covers. Scientia Horticulturae, 87(1-2), 139-145. DOI 10.1016/s0304-4238(00)00172-2

8. Ibarra-Jiménez L., Flores-Velásquez J., Quezada M.R. 2001. Desarrollo y rendimiento de melón (Cucumis melo L.) con relación al tiempo de permanencia de la cubierta flotante. Revista Chapingo, Serie Horticultura, 7(1), 95-109.

9. Kosterna E. 2014. The effect of covering and mulching on the soil temperature, growth and yield of tomato. Folia Horticulturae, 26(2), 91-101. DOI 10.2478/fhort-2014-0009
10. Kosterna E., Zaniewicz-Bajkowska A., Franczuk J., Rosa R. 2009. Effect of foliar feeding on the field level and quality of six large-fruit melon $(\mathrm{Cu}$ cumis melo L.) cultivars. Acta Scientiarum Polonorum, Hortorum Cultus, 8(3), 13-24.

11. Kruk K. 1995. Warzywa dyniowate w uprawie polowej (ogórek, dynia olbrzymia, dynia zwyczajna, melon). Synteza Wyników Doświadczeń Odmianowych. Zeszyty COBORU w Słupi Wielkiej, 1044, pp. 32.

12. Lamont W.J. 2005. Plastics: Modifying microclimate for the production of vegetable crops. HortTechnology, 15, 477-481.

13. Majkowska-Gadomska J. 2009. Mineral content of melon fruit (Cucumis melo L.). Journal of Elementology, 14(4), 717-727. DOI 10.5601/ jelem.2009.14.4.717-727.

14. Majkowska-Gadomska, J. (2010). Badania nad oddziaływaniem bezpośredniego osłaniania roślin i ściółkowania gleby na wzrost rozwój oraz plonowanie melona (Cucumis melo L.). Wydawnictwo UW-M w Olsztynie. Rozpr. hab., 159, pp. 111.

15. Rosa R. 2014. Response of sweet corn cultivated in eastern Poland to different sowing dates and covering with non-woven PP. Part I. Corn yields. Acta Scientiarum Polonorum, Agricultura, 13(4), 93-112.

16. Sady W. 2000. Nawożenie warzyw polowych. Plantpress, Kraków.

17. Santos F.G.B., Negreiros M.Z., Medeiros J.F., Sousa Nunes G.H., Medeiros D.C., Granjeiro L.C. 2015. Produção e qualidade de melão Cantaloupe em cultivo protegido temporariamente com agrotêxtil em Mossoró, Rio Grande do Norte. Revista Ceres, Viçosa 62(1), 93-100.

18. Shin Y.S., Lee J.E., Yeon I.K., Cheung J.D., Choi S.Y., Lee K.D. 2009. Effect of nonwoven fabrics materials on the growth and yield of Korea Melon (Cucumis melo L. var. makuwa Mak.). Journal of Bio Environment Control, 18(2), 101-106.

19. Siwek P., Lipowiecka M. 2003. Efektywność ekonomiczna stosowania osłon z tworzyw sztucznych w uprawie ogórków na wczesny zbiór. Folia Horticulturae, Supl., 2, 358-360.

20. Waterer D. 2003. Yields and economics of high tunnels for production of warm season vegetable crops. HortTechnology, 13, 339-343.

21. Waterer D. 2010. Evaluation of biodegradable mulches for production of warm-season vegetable crops. Canadian Journal of Plant Science, 90, 73743. DOI 10.4141/cjps10031

22. Wierzbicka B., Kuskowska M. 2000. The effect of soil temperature on yield of lettuce and cucumber grown under plastic cover. Hort. Veg. Grow., 19(3), 195-202.

23. World reference base for soil resources 2014. Update 2015. World Soil Resources Reports No. 106, FAO, Rome.

24. www.fresh-market.pl [access: 4.01.2016]

25. Yilmaz H., Demircan V., Kurtluk S. 2011. An economic analysis of open field melon (Cucumis melo L.) production in Cankiri province of Turkey. Bulgarian Journal of Agricultural Science, 17(4), 484- 490. 